\title{
Effects of dietary protein level on intake, digestibility, and energy expenditure in dairy heifers
}

\section{Efeitos do nível de proteína na ingestão, digestibilidade, e gasto energético em novilhas leiteiras}

\author{
Laylles Costa Araújo ${ }^{1 *}$; Eriton Egidio Lisboa Valente ${ }^{2}$; Valdir da Trindade Filipini; \\ Silvana Teixeira Carvalho' ${ }^{2}$, Mariane Stahlhofer ${ }^{4}$; Carla Heloisa Avelino Cabral ${ }^{5}$; \\ Matheus Leonardi Damasceno ${ }^{4}$; Mariana Barbizan ${ }^{4}$
}

\begin{abstract}
Highlights:
The objective of livestock production is obtain to energy and protein of quality. Dietary balance determines the efficiency of dietary protein use by the animal. Estimating nitrogen excretion by livestock is be important.
\end{abstract}

\begin{abstract}
Balancing diets for protein affects both protein and energy use efficiency in cattle. This study aimed to evaluate the effects of dietary protein level on intake, digestibility and energy expenditure in Holstein heifers. Four Holstein heifers with a mean BW of $266.5 \pm 10.7 \mathrm{~kg}$ were distributed in a $4 \mathrm{x} 4$ balanced Latin square design. Each period was comprised of $14 \mathrm{~d}$ for adaptation and $6 \mathrm{~d}$ for samplings. The heifers were fed diets with $9,12,15$ and $18 \%$ of crude protein (CP). Total feces and urine were collected. Rumen fluid was collected at 2, 4, 6 and $8 \mathrm{~h}$ after feeding. The energy expenditure was evaluated at 6 a.m., 12 a.m., 6 p.m. and 12 p.m. by a closed-circuit mask technique. The intake of dry matter (DM), organic matter $(\mathrm{OM})$ and neutral detergent fiber $(\mathrm{NDF})$ were similar between treatments $(\mathrm{P}>0.05)$. Although the NDF digestibility was not changed (P>0.05), the digestibilities of DM, OM, CP, nonfibrous carbohydrates, and total digestible nutrients increased linearly $(\mathrm{P}<0.05)$ with increasing $\mathrm{CP}$ levels in the diet. Urinary urea nitrogen excretion and nitrogen retained increased linearly $(\mathrm{P}<0.01)$ with increasing CP levels. Dietary $\mathrm{CP}$ levels did not affect $(\mathrm{P}=0.53)$ energy expenditure in heifers. Ruminal ammonia-nitrogen concentration peaked at 2-4 h after feeding. Increasing dietary CP levels from 9 to $18 \%$ does not affect feed intake and energy expenditure in heifers. However, it improves the digestibility of $\mathrm{OM}$ and nitrogen retention.
\end{abstract}

Key words: Cattle. Intake. Nitrogen excretion. Urea.

1 Discente do Curso de Doutorado em Zootecnia, Universidade Estadual Paulista "Júlio de Mesquita Filho, UNESP, Jaboticabal, SP, Brasil. E-mail: laylles_araujo@hotmail.com

2 Profs., Drs., Programa de Pós-Graduação em Zootecnia, Universidade Estadual do Oeste do Paraná, UNIOESTE, Marechal Cândido Rondon, PR, Brasil. E-mail: eritonvalente@yahoo.com.br; silteixeira@gmail.com

3 M.e em Zootecnia, UNIOESTE, Marechal Cândido Rondon, PR, Brasil. E-mail: valdirfilipini@bol.com.br

4 Discentes do Curso de Doutorado em Zootecnia, UNIOESTE, Marechal Cândido Rondon, PR, Brasil. E-mail: marianefj@gmail. com; matheusld31@gmail.com; mari_mn10@hotmail.com

5 Prof $^{\mathrm{a}} \mathrm{Dr}^{\mathrm{a}}$, Instituto de Ciências Agrárias e Tecnológicas, Fundação Universidade Federal do Mato Grosso, UFMT, Rondonópolis, MT, Brasil. E-mail: cabralcha@hotmail.com

* Author for correspondence 
O balanceamento das dietas proteicas afeta tanto a eficiência no uso de proteínas quanto a eficiência no uso de energia em bovinos. Este estudo teve como objetivo avaliar os efeitos dos níveis de proteína na dieta sobre consumo, digestibilidade e gasto de energia em novilhas Holandesas. Quatro novilhas Holandesas com um peso corporal (PC) médio de 266,5 $\pm 10,7 \mathrm{~kg}$ foram distribuídas em delineamento quadrado latino $4 \times 4$. Cada período era composto de $14 \mathrm{~d}$ para adaptação e $6 \mathrm{~d}$ para amostragens. As novilhas foram alimentadas com 9,12,15 e 18\% de proteína bruta (PB). Fezes e urina totais foram coletadas. O líquido ruminal foi coletado às $2,4,6$ e $8 \mathrm{~h}$ após a alimentação. $\mathrm{O}$ gasto de energia foi avaliado às $6 \mathrm{~h}, 12 \mathrm{~h}, 18 \mathrm{~h}$ e $12 \mathrm{~h}$ por uma técnica de máscara de circuito fechado. O consumo de matéria seca (MS), matéria orgânica (MO) e fibra em detergente neutro (FDN) foram similares entre os tratamentos $(\mathrm{P}>0,05)$. Embora a digestibilidade do FDN não tenha sido alterada $(\mathrm{P}>0,05)$, a digestibilidade de MS, MO, PB, carboidratos não-fibrosos e nutrientes digestíveis totais aumentou linearmente $(\mathrm{P}<0,05)$ com o aumento dos níveis de $\mathrm{PB}$ na dieta. A excreção de uréia urinária e o nitrogênio retido aumentaram linearmente $(\mathrm{P}<0,01)$. Os níveis de $\mathrm{PB}$ na dieta não afetaram $(\mathrm{P}=0,53)$ o gasto de energia em novilhas. A concentração de nitrogênio amoniacal atingiu o pico em 2-4 h após a alimentação. $\mathrm{O}$ aumento dos níveis dietéticos de PB de 9 para 18\% não afeta o consumo de ração e o gasto de energia em novilhas. Entretanto, melhora a digestibilidade da $\mathrm{MO}$ e a retenção de nitrogênio.

Palavras-chave: Bovinos. Consumo. Excreção de nitrogênio. Urea.

\section{Intruction}

Balancing diets for protein may affect nitrogen use by cattle (Dong, Zhang, Zhang, Tu, \& Diao, 2017). Although the primary purpose of livestock is to convert carbohydrates and proteins from feedstuffs into food for humans, only 5 to $40 \%$ of $\mathrm{N}$ as feed usually meets the target (Calsamiglia, Ferret, Reynolds, Kristensen, \& Van Vuuren, 2010)and while major improvements in our understanding of $\mathrm{N}$ requirements and metabolism have been achieved, the overall efficiency remains low In general, maximal efficiency of $\mathrm{N}$ utilization will only occur at the expense of some losses in production performance. However, optimal production and $\mathrm{N}$ utilization may be achieved through the understanding of the key mechanisms involved in the control of $\mathrm{N}$ metabolism. Key factors in the rumen include the efficiency of $\mathrm{N}$ capture in the rumen (grams of bacterial $\mathrm{N}$ per grams of rumen available N. The remaining is excreted in the feces and urine. Nitrogen excretion in the environment has a negative impact on the quality of air, soil, and water (Richardson, Felgate, Watmough, Thomson, \& Baggs, 2009), leading to economic losses.
An adequate supply of rumen degradable protein (RDP) ensures microbial growth by optimizing fermentative digestion (Leng, 1990). In a low-quality diet, fiber digestibility increases with increasing crude protein (CP) level up to 7-8 $\%$ (Lazzarini et al., 2009). On the other hand, dry matter intake usually is optimized up to the level of 10\% CP (Detmann, Valente, Batista, \& Huhtanen, 2014 ; Sampaio et al., 2010)digestibility, and microbial protein synthesis in cattle fed low-quality tropical forage were assessed. Five rumen fistulated crossbred Holstein x Gir heifers were used, with initial average live weight of $180+/-21 \mathrm{~kg}$. Signal grass (Brachiaria decumbens. It indicates that the metabolic effects of protein positively affect feed intake, besides its effects on ruminal degradation (Detmann et al., 2014)using a meta-analytical approach. The dataset used to evaluate the ENU was compiled from 10 experiments carried out in Brazil, which were published between 2009 and 2012, totalling 47 treatment means. To compose the dataset for animal performance evaluation, mean treatment values were collected from 44 experiments involving grazing beef cattle, which were published 
in Brazil from 2001 to 2012, totalling 182 treatment means. The relationships between variables were evaluated using linear or non-linear mixed models, taking into account the random variations among experiments. There was no association between ENU and the balance of nitrogen in the rumen and the efficiency of microbial synthesis in the rumen $(\mathrm{P}>0.05$.

Balancing diets for protein affects both protein and energy use efficiency in cattle. Excess protein in the diet increases nitrogen excretion in the urine as urea. The synthesis of urea is an energy-consuming process (Nelson \& Cox, 2008). Therefore, excess nitrogen in the diet increases urea excretion in the urine and may decrease the energy available for retention, thereby decreasing the efficiency of nitrogen retention in the body.

Some studies reported a reduction in metabolizable energy or net energy in diets when digestible protein was fed in excess of requirements (Reynolds, Crompton, \& Mills, 2011). On the other hand, other studies did not observe an effect of excessive protein in diets on the energy metabolism in the liver, which is associated with the urea cycle (Reynolds et al., 2011). However, amino acids may also reduce energy utilization in diets with excess protein (Reynolds, 2006). Therefore, it is not completely clear whether excess protein increases the energy expenditure due to the use of energy for nitrogen excretion in the urine. This study aimed to evaluate the effects of dietary protein level on intake, digestibility and energy expenditure in Holstein heifers.

\section{Material and Methods}

This study was approved by the Ethics Committee on Animal Use (CEUA/Unioeste - under the protocol number 29/15), in accordance with the ethical principles of animal experimentation established by the Brazilian Council of Animal Experimentation Control (CONCEA).

\section{Animals and diets}

Four Holstein heifers with a mean body weight (BW) of $266.5 \pm 10.7 \mathrm{~kg}$ were distributed in a 4 x 4 balanced Latin square design. Each period was comprised of $14 \mathrm{~d}$ for adaptation and $6 \mathrm{~d}$ for samplings, $80 \mathrm{~d}$ overall. The heifers were kept in individual pens in a barn and received diets with $9,12,15$ and $18 \%$ of CP (Table 1). The diet was offered twice daily in equal amounts at 8 a.m. and 4 p.m., allowing approximately $10 \%$ of orts. Samples of feed and orts were collected from d 15 to d 19 of each period. The samples were kept at $-20{ }^{\circ} \mathrm{C}$ for later analysis. 
Table 1

Ingredients and chemical composition of the diet offered

\begin{tabular}{lcccc}
\hline & \multicolumn{4}{c}{ Dietary CP levels } \\
\hline Item & $9 \%$ & $12 \%$ & $15 \%$ & $18 \%$ \\
\hline Ingredients, \% DM & & & & \\
Bermuda grass hay & 45.0 & 45.0 & 45.0 & 45.0 \\
Ground corn & 53.8 & 46.5 & 40.0 & 32.7 \\
Soybean meal & - & 7.3 & 13.8 & 21.1 \\
Sodium bicarbonate & 0.5 & 0.5 & 0.5 & 0.5 \\
Mineral mix & 0.7 & 0.7 & 0.7 & 0.7 \\
\hline Chemical composition & & & & 84.6 \\
DM, \% & 84.3 & 85.4 & 85.1 & 94.5 \\
OM, \% of DM & 96.7 & 96.7 & 95.4 & 17.9 \\
CP, \% of DM & 9.1 & 12.1 & 14.8 & 54.5 \\
RDP, $\%$ of CP & 48.5 & 49.9 & 51.9 & 42.5 \\
NDF, \% of DM & 42.2 & 42.3 & 42.4 & 1.9 \\
EE & 2.5 & 2.3 & 2.1 & 33.2 \\
NFC & 38.5 & 38.0 & 35.9 & \\
\hline
\end{tabular}

${ }^{1}$ Provided (kg of DM): Ca - 215 g, P -65 g, Co -45 mg, Mg - 12 g, Mn - 425 mg, Zn - 1900 mg, Se - 35 mg, I - 65 mg, S - 10 $\mathrm{g}, \mathrm{F}-650 \mathrm{mg}, \mathrm{Fe}-1700 \mathrm{mg}, \mathrm{Cu}-800 \mathrm{mg}, \mathrm{Na}-75 \mathrm{~g}$.

${ }_{2}^{2}$ Predicted from the National Research Council [NRC] (2001) model.

\section{Measurements and sampling}

Total feces and urine were collected from d 15 to d 19 of each period. The feces were collected from the rubber floor. The urine was collected using a rubber funnel connected to a plastic pipe and a plastic container with $200 \mathrm{~mL}$ of $20 \% \mathrm{H}_{2} \mathrm{SO}_{4}$. The total urine volume was weighed daily, and 50 $\mathrm{mL}$ was sampled and kept at $-20{ }^{\circ} \mathrm{C}$. The nitrogen balance was determined as the total nitrogen intake minus the nitrogen excretion in urine and feces.

The energy expenditure ( $\mathrm{kcal} /$ minute, $\mathrm{kg}^{0.75}$ ) was calculated by multiplying the oxygen uptake $\left(\mathrm{VO}_{2}\right.$; $\mathrm{L} /$ minute) by 4.89 (McLean, 1972). The $\mathrm{VO}_{2}$ was evaluated at 6 a.m., 12 a.m., 6 p.m. and 12 p.m. from d 15 to $\mathrm{d} 19$ of each period using the closedcircuit mask technique. For measuring $\mathrm{VO}_{2}$, a mask was held over the heifers' muzzle by inflating a rubber chamber. Then the closed-circuit system was connected to the mask by two flexible tubes ( 75 $\mathrm{mm}$ ), and the air was continuously cycled through the mask and the closed system by fans. When the respiratory system was closed, a measurement cycle started. After 2 minutes, the circuit was opened, and the internal air was renewed every 3 minutes. The oxygen concentration in the closedcircuit was recorded as the mask was connected (initial evaluation) and immediately before opening the circuit to renew the air (final evaluation). Each measurement cycle was repeated three times per heifer each time per period. Therefore, each treatment had a total of $240 \mathrm{VO}_{2}$ evaluations (3 replicates/evaluation, 4 evaluations/d, $5 \mathrm{~d} /$ period and 4 periods). The temperature and humidity inside and outside the chamber during the evaluations were recorded every minute. The $\mathrm{VO}_{2}$ (L/minute) was determined by the following equation:

$$
V O_{2}=\left[\left(\mathrm{C}_{\mathrm{i}}-C_{\mathrm{f}}\right) \times 500\right] / \mathrm{t}
$$

where $\mathrm{C}_{\mathrm{i}}$ is the initial $\mathrm{O}_{2}$ concentration $(\%), \mathrm{C}_{\mathrm{f}}$ is the final $\mathrm{O}_{2}$ concentration (\%), 500 is the volume of the chamber $(\mathrm{L})$, and $\mathrm{t}$ is the time of the evaluation (minutes). 
After each $\mathrm{VO}_{2}$ measurement, $10 \mathrm{~mL}$ of blood was taken through the jugular vein. The blood was centrifuged at 2,000 $\mathrm{g}$ for $15 \mathrm{~min}$ to obtain the serum, which was kept at $-20{ }^{\circ} \mathrm{C}$ for later analysis. Rumen fluid was collected at $\mathrm{d} 20$ via the esophagus using a rubber tube and a vacuum pump. The samples were collected before feeding at 8 a.m. and 2, 4, 6 and 8 $\mathrm{h}$ after feeding. The $\mathrm{pH}$ was measured immediately after the collection. Subsequently, a $50 \mathrm{~mL}$ aliquot was taken, and $1 \mathrm{~mL}$ of $50 \% \mathrm{H}_{2} \mathrm{SO}_{4}$ was added. The material was kept at $-20{ }^{\circ} \mathrm{C}$.

The amount of nitrogen retained in the body (NR) was calculated by the difference between the nitrogen intake and excretion as feces and urine. The apparent nitrogen use efficiency (NUE) was calculated as the proportion between NR to nitrogen ingested. The heifers were weighed at the beginning and end of each period before fed, at 7 a.m.

\section{Chemical analysis}

Samples of feed, orts, and feces were dried at $55^{\circ} \mathrm{C}$ for $72 \mathrm{~h}$ and ground to pass a $1-\mathrm{mm}$ sieve to be analyzed for the dry matter content (method 920.39), organic matter (method 942.05), ether extract (method 920.39) and nitrogen compounds (method 954.01), as described by the (Association of Official Analytical Chemists [AOAC], 1990). In the analysis of ash and protein-free neutral detergent fiber (aNDF), the samples were treated with heat-stable amylase, without sodium sulfite, and corrected for residual ash (Mertens, 2002) and nitrogenous compounds were analyzed as described by Licitra, Hernandez and Van Soest (1996)1991; Sniffen et al., 1992. The non-fibrous carbohydrates $(\mathrm{NFC})$ were calculated as NFC $=100-(\mathrm{aNDF}+\mathrm{CP}$ $+\mathrm{EE}+\mathrm{ash})$. The total digestible nutrients (TDN) were calculated as described by the NRC (2001).

The urine was analyzed for nitrogen compounds as described above. Additionally, the urine and serum samples were analyzed for urea content with the use of a commercial kit (Gold Analisa, Belo Horizonte, MG, Brazil). Rumen fluid was analyzed for ammonia nitrogen (RAN) concentration using the colorimetric method Chaney and Marbach (1962).

\section{Statistical analysis}

The variables were evaluated using the MIXED procedure of SAS (Statistical Analysis System Institute [SAS Institute], 2017) according to the following model:

$Y_{i j k l}=\mu+C P_{i}+T_{j}+A_{k}+P_{l}+(\mathrm{CPxT})_{i j}+e_{i j k l}$,

where Yijkl is the dependent variable; $\mu$ is the overall mean; $\mathrm{CP} i$ is the fixed effect of the $i$-th $\mathrm{CP}$ level; $\mathrm{T} j$ is the fixed effect of $j$-th time of collection; $\mathrm{A}_{k}$ is the random effect of the $k$-th animal; $\mathrm{P}_{l}$ is the random effect of the $l$-th experimental period; $(\mathrm{CPxT})_{i j}$ is the interaction between the main effects; and $\mathrm{e}_{i j k l}$ is the random error associated with $\mathrm{Y}_{i j k l}$, distributed as $\mathrm{e}_{i j k l} \sim \mathrm{N}\left(0, \sigma_{\mathrm{e}}{ }^{2}\right)$.

Before determining the final statistical model, all possible interactions were tested $(P \leq 0.05)$. When treatment or time was significant, linear and quadratic effects were evaluated using orthogonal contrast. Significant effects were determined at $P \leq$ 0.05 .

\section{Results}

The average daily gain was extremely high for dairy heifers, with a mean of $1 \pm 0.03 \mathrm{~kg} / \mathrm{d}$. According to the NRC (2001), the crude protein requirement was $0.98 \mathrm{~kg} /$ day with an average TDN requirement of $4.96 \mathrm{~kg} / \mathrm{d}$ for the observed gain. This $\mathrm{CP}$ requirement was reached between the levels of 12 and $15 \%$ of CP (Table 2). The increase in dietary CP levels did not affect $(P>0.05)$ the TDN intake. The mean TDN intake $(4.72 \mathrm{~kg} / \mathrm{d})$ was similar to the recommended by the NRC (2001). 
Table 2

Effect of dietary protein levels on the feed intake

\begin{tabular}{|c|c|c|c|c|c|c|c|}
\hline \multirow[b]{2}{*}{ Item } & \multicolumn{4}{|c|}{ Dietary protein levels } & \multirow{2}{*}{ SEM $^{1}$} & \multicolumn{2}{|c|}{$\mathrm{P}$-value ${ }^{2}$} \\
\hline & $9 \%$ & $12 \%$ & $15 \%$ & $18 \%$ & & $\mathrm{~L}$ & Q \\
\hline $\mathrm{DM}^{3}$ & 23.5 & 22.37 & 22.0 & 22.2 & 1.9 & 0.097 & 0.235 \\
\hline $\mathrm{OM}^{4}$ & 22.4 & 21.6 & 20.7 & 20.8 & 1.55 & 0.081 & 0.454 \\
\hline $\mathrm{CP}^{5}$ & 2.1 & 2.8 & 3.3 & 4.2 & 0.26 & $<0.001$ & 0.415 \\
\hline $\mathrm{EE}^{6}$ & 0.4 & 0.4 & 0.4 & 0.4 & 0.04 & 0.765 & 0.790 \\
\hline $\mathrm{aNDF}^{7}$ & 9.7 & 9.2 & 9.2 & 9.2 & 0.66 & 0.309 & 0.465 \\
\hline $\mathrm{NFC}^{8}$ & 10.2 & 8.2 & 7.8 & 7.6 & 0.72 & 0.024 & 0.155 \\
\hline $\mathrm{DOM}^{9}$ & 14.2 & 14.0 & 14.8 & 15.0 & 1.1 & 0.350 & 0.719 \\
\hline $\mathrm{TDN}^{10}$ & 14.4 & 14.1 & 15.0 & 15.7 & 1.04 & 0.170 & 0.451 \\
\hline CP:DOM ${ }^{11}$ & 145.5 & 200.0 & 225.9 & 276.4 & 8.7 & $<0.001$ & 0.633 \\
\hline
\end{tabular}

${ }^{1} \mathrm{SEM}=$ standard error of the mean; ${ }^{2} \mathrm{~L}$ and $\mathrm{Q}=$ linear and quadratic effects relative to the dietary protein level; ${ }^{3} \mathrm{DM}=\mathrm{dry}$ matter $(\mathrm{g} /$ $\mathrm{kg}$ of $\mathrm{BW}) ;{ }^{4} \mathrm{OM}=\operatorname{organic}$ matter $(\mathrm{g} / \mathrm{kg}$ of BW $) ;{ }^{5} \mathrm{CP}=$ crude protein $(\mathrm{g} / \mathrm{kg}$ of BW $) ;{ }^{6} \mathrm{EE}=$ ether extract $(\mathrm{g} / \mathrm{kg}$ of BW $) ;{ }^{7} \mathrm{aNDF}=\mathrm{ash}$ and protein-free neutral detergent fiber $(\mathrm{g} / \mathrm{kg}$ of $\mathrm{BW}) ;{ }^{8} \mathrm{NFC}=$ non-fibrous carbohydrates $(\mathrm{g} / \mathrm{kg}$ of BW$) ;{ }^{9} \mathrm{DOM}=$ digestible organic matter $(\mathrm{g} / \mathrm{kg}$ of $\mathrm{BW}) ; \mathrm{TDN}^{10}=$ total digestible nutrients $(\mathrm{g} / \mathrm{kg}$ of $\mathrm{BW}) ;{ }^{11} \mathrm{CP}: \mathrm{DOM}=$ crude protein to digestible organic matter ratio $(\mathrm{g} / \mathrm{kg})$.

The intakes of DM, OM, EE, aNDF and digestible organic matter $(\mathrm{DOM})$ were similar between treatments $(\mathrm{P}>0.05)$. However, the NFC intake decreased linearly $(\mathrm{P}<0.05)$ with increasing $\mathrm{CP}$ levels in the diet. The ratio of $\mathrm{CP}$ intake to DOM intake $(\mathrm{CP}: \mathrm{DOM})$ increased linearly $(\mathrm{P}<0.01)$ with increasing CP levels, ranging from 146 to $276 \mathrm{~g} / \mathrm{kg}$ (Table 2).

Although the digestibility of NDF and EE did not change $(\mathrm{P}>0.05)$, the digestibilities of $\mathrm{DM}$, $\mathrm{OM}, \mathrm{CP}$, and NFC increased linearly $(\mathrm{P}<0.05)$ with increasing $\mathrm{CP}$ levels in the diet, as well as the TDN concentration (Table 3).

Table 3

\section{Effect of dietary protein levels on the coefficient of apparent digestibility}

\begin{tabular}{|c|c|c|c|c|c|c|c|}
\hline \multirow[b]{2}{*}{ Item } & \multicolumn{4}{|c|}{ Dietary protein level } & \multirow{2}{*}{$\mathrm{SEM}^{1}$} & \multicolumn{2}{|c|}{ P-value ${ }^{2}$} \\
\hline & $9 \%$ & $12 \%$ & $15 \%$ & $18 \%$ & & $\mathrm{~L}$ & Q \\
\hline $\mathrm{DM}^{3}$ & 0.618 & 0.658 & 0.693 & 0.697 & 0.012 & $<0.001$ & 0.069 \\
\hline $\mathrm{OM}^{4}$ & 0.637 & 0.680 & 0.712 & 0.727 & 0.011 & $<0.001$ & 0.297 \\
\hline $\mathrm{CP}^{5}$ & 0.434 & 0.588 & 0.676 & 0.732 & 0.036 & $<0.001$ & 0.108 \\
\hline $\mathrm{aNDF}^{6}$ & 0.713 & 0.672 & 0.707 & 0.680 & 0.021 & 0.388 & 0.682 \\
\hline $\mathrm{EE}^{7}$ & 0.512 & 0.505 & 0.491 & 0.440 & 0.054 & 0.342 & 0.686 \\
\hline $\mathrm{NFC}^{8}$ & 0.601 & 0.695 & 0.747 & 0.799 & 0.037 & $<0.001$ & 0.624 \\
\hline
\end{tabular}

${ }^{1} \mathrm{SEM}=$ standard error of the mean; ${ }^{2} \mathrm{~L}$ and $\mathrm{Q}=$ linear and quadratic effects relative to the dietary protein level; ${ }^{3} \mathrm{DM}=\mathrm{dry}$ matter $(\mathrm{kg} / \mathrm{kg}) ;{ }^{4} \mathrm{OM}=$ organic matter $(\mathrm{kg} / \mathrm{kg}) ;{ }^{5} \mathrm{CP}=$ crude protein $(\mathrm{kg} / \mathrm{kg}) ;{ }^{6} \mathrm{aNDF}=$ ash and protein-free neutral detergent fiber $(\mathrm{kg} / \mathrm{kg}) ;$ ${ }^{7} \mathrm{EE}=$ ether extract $(\mathrm{kg} / \mathrm{kg}) ;{ }^{8} \mathrm{NFC}=$ non-fibrous carbohydrates $(\mathrm{kg} / \mathrm{kg})$. 
The $\mathrm{pH}$ was close to neutrality and similar $(\mathrm{P}>$ 0.05 ) between treatments and sampling time (Table 4). The CP levels had a positive linear effect on serum urea nitrogen. The RAN was affected $(\mathrm{P}<$ $0.01)$ by $\mathrm{CP}$ level, time and interaction between $\mathrm{CP}$ level and time (Table 4).

Table 4

Mean rumen $\mathrm{pH}$ at different sampling times, serum urea nitrogen and ruminal ammonia-nitrogen concentration (mg/dL) of Holstein heifers fed different levels of crude protein

\begin{tabular}{|c|c|c|c|c|c|c|c|c|}
\hline \multirow[t]{2}{*}{ Item } & \multicolumn{4}{|c|}{ Dietary protein level } & \multirow[t]{2}{*}{ SEM $^{1}$} & \multicolumn{3}{|c|}{ P-value ${ }^{2}$} \\
\hline & $9 \%$ & $12 \%$ & $15 \%$ & $18 \%$ & & Treatment & Time & $\begin{array}{c}\text { Treatment } \\
\text { x Time }\end{array}$ \\
\hline $\mathrm{pH}$ & 6.86 & 6.83 & 6.86 & 6.83 & 0.06 & 0.932 & 0.286 & 0.833 \\
\hline $\mathrm{SUN}^{3}$ & 7.4 & 10.3 & 14.1 & 18.4 & 1.27 & $<0.001$ & $<0.001$ & 0.330 \\
\hline RAN $^{4}$ & 10.9 & 13 & 19.09 & 28.3 & 1.61 & $<0.001$ & $<0.001$ & 0.006 \\
\hline
\end{tabular}

${ }^{1} \mathrm{SEM}=$ standard error of the mean; ${ }^{2} \mathrm{~L}$ and $\mathrm{Q}=$ linear and quadratic effects relative to the dietary protein level; ${ }^{3} \mathrm{SUN}=\mathrm{serum}$ urea nitrogen $(\mathrm{mg} / \mathrm{dL}) ;{ }^{4} \mathrm{RAN}=$ ruminal ammonia-nitrogen concentration $(\mathrm{mg} / \mathrm{dL})$.

Therefore, the responses to the treatments were dependent on the sampling time (Figure 1). The
NAR peaked at 2-4 $\mathrm{h}$ after feeding, and it increased with increasing dietary CP levels (Figure 1).

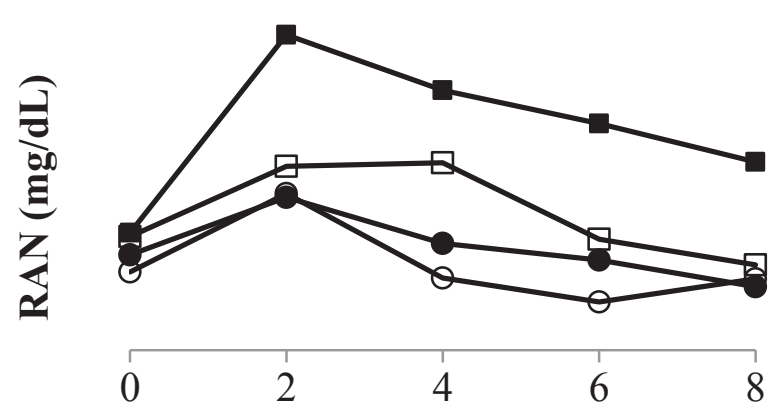

Time (h)

Figure 1. Effect of time after feeding on ruminal ammonia-nitrogen concentration (RAN) in diets with $9 \%(\circ), 12 \%(\bullet), 15 \%(\square)$ and 18\% (घ) of crude protein (CP). CP level, $\mathrm{P}<0.01$; time, $\mathrm{P}<0.01$; $\mathrm{CP}$ level $\times$ time, $\mathrm{P}=0.01$.

Both urinary nitrogen (UN) and urinary urea nitrogen (UUN) excretion increased $(\mathrm{P}<0.01)$ with increasing CP levels (Table 5). However, nitrogen excretion in feces was not affected $(\mathrm{P}>0.05)$ by $\mathrm{CP}$ levels. The NR increased linearly $(\mathrm{P}=0.022)$ with increasing $\mathrm{CP}$ levels in the diet. When the dietary
CP level was increased from $9 \%$ to $18 \%$, both UUN and NR increased by $330 \%$. On the other hand, when the dietary CP level was increased from $12 \%$ to $18 \%$, UUN increased by $139 \%$ and NR by $43 \%$. NUE was similar $(\mathrm{P}>0.05)$ between treatments. 
Table 5

Effect of dietary protein level on nitrogen excretion and balance

\begin{tabular}{lccccccc}
\hline & \multicolumn{3}{c}{ Dietary protein level } & & SEM $^{1}$ & \multicolumn{2}{c}{ P-value $^{2}$} \\
\hline Item & $9 \%$ & $12 \%$ & $15 \%$ & $18 \%$ & & $\mathrm{~L}$ & $\mathrm{Q}$ \\
\hline $\mathrm{UUN}^{3}$ & 0.095 & 0.175 & 0.272 & 0.419 & 0.027 & $<0.001$ & 0.211 \\
$\mathrm{UN}^{4}$ & 0.131 & 0.209 & 0.307 & 0.420 & 0.016 & $<0.001$ & 0.156 \\
$\mathrm{FN}^{5}$ & 0.202 & 0.199 & 0.185 & 0.195 & 0.027 & 0.366 & 0.468 \\
$\mathrm{NR}^{6}$ & 0.025 & 0.066 & 0.071 & 0.104 & 0.030 & 0.027 & 0.831 \\
$\mathrm{NUE}^{7}$ & 0.056 & 0.133 & 0.127 & 0.134 & 0.059 & 0.236 & 0.424 \\
\hline
\end{tabular}

${ }^{1} \mathrm{SEM}=$ standard error of the mean; ${ }^{2} \mathrm{~L}$ and $\mathrm{Q}=$ linear and quadratic effects relative to the dietary protein level; ${ }^{3} \mathrm{UUN}=$ urinary urea nitrogen $(\mathrm{g} / \mathrm{kg}$ of $\mathrm{BW}) ;{ }^{4} \mathrm{UN}=$ urinary nitrogen $(\mathrm{g} / \mathrm{kg}$ of $\mathrm{BW}) ;{ }^{5} \mathrm{FN}=$ fecal nitrogen $(\mathrm{g} / \mathrm{kg}$ of $\mathrm{BW}) ;{ }^{6} \mathrm{NR}=$ nitrogen retained in the body $(\mathrm{g} / \mathrm{kg}$ of $\mathrm{BW}) ;{ }^{7} \mathrm{NUE}=$ apparent nitrogen use efficiency $(\mathrm{g} / \mathrm{g})$.

The dietary CP level did not affect $(\mathrm{P}=0.53)$ the energy expenditure in heifers. However, the energy expenditure was higher $(\mathrm{P}<0.01)$ at 6 a.m. and 0 a.m. The lowest energy expenditure $(\mathrm{P}<0.01)$ was observed at 6 p.m. (Figure 2). No interaction was found between $\mathrm{CP}$ level and time $(\mathrm{P}=0.77)$.
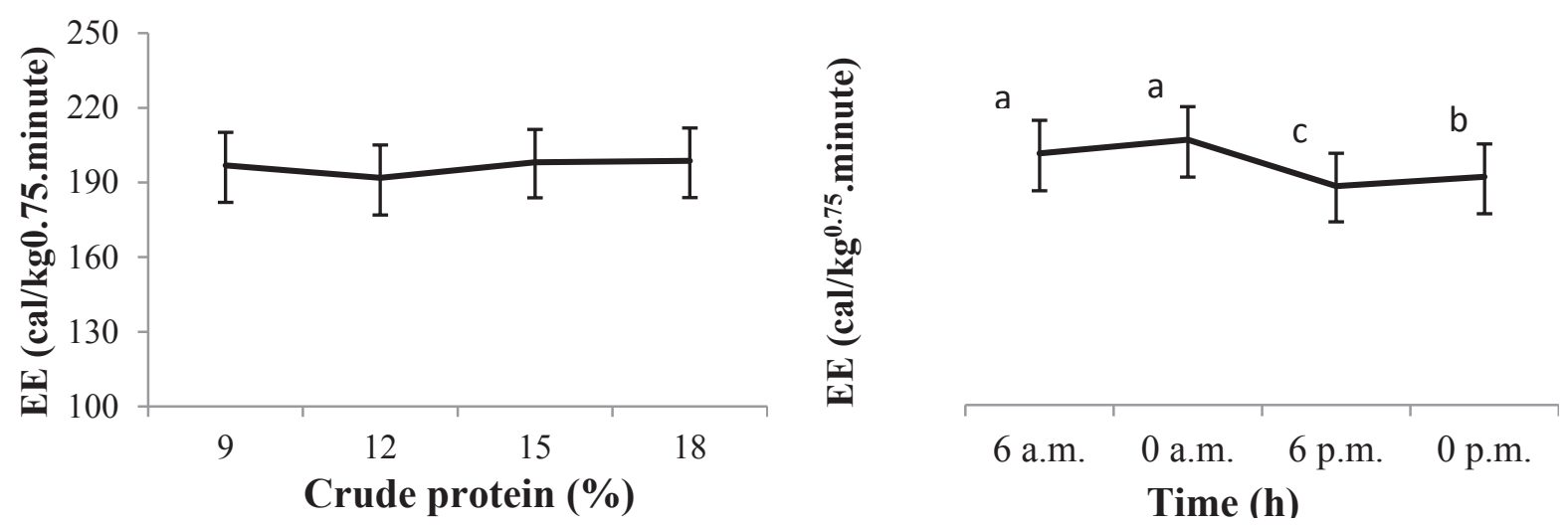

Figure 2. Effect of dietary crude protein level and time on energy expenditure (EE).

\section{Discussion}

Increases in dry matter intake (DMI) are expected when $\mathrm{CP}$ is provided in a low-quality diet (Leng, 1990). However, feed intake increases up to the level of 10\% CP (Sampaio et al., 2010). Excess circulating ammonia in the blood can lead to impaired brain functioning due to the energy deficit, causing discomfort to the animals and resulting in a reduction in voluntary intake as a compensatory mechanism (Detmann, Paulino, Valadares, \& Lana, 2007). The increase in dietary CP from a low $(9 \%)$ to a high level (18\%) did not affect the DMI intake (Table 2) because other diet-related factors may have more evident effects on DMI than CP levels.

Although dietary CP levels affect feed intake, the availability of nitrogen to rumen microorganisms should be considered. In a study with dairy cows, Mutsvangwa, Davies, McKinnon and Christensen (2016) did not find an effect of CP levels on DM intake; however, feed intake increased when the proportion of rumen-degradable protein (RDP) in low-protein diets $(14.9 \% \mathrm{CP})$ was increased from 
$62.5 \%$ to $69 \%$ of RDP. However, the opposite trend was observed for cows fed high-CP diets $(17.5 \%$ CP). Therefore, adequate levels of RDP stimulate DMI. Low levels of RDP (Table 1) are not the most plausible explanation for the lack of response in DMI since cows fed the $18 \% \mathrm{CP}$ diet had similar DMI compared to cows fed the $9 \%$ CP diet, even though the provided RDP increased twice. Therefore, factors associated with the regulation of feed intake, other than microbial activity, were more critical in determining the DMI.

The NFC intake decreased linearly with the increasing replacement of corn with soybean meal, consequently reducing the NFC content in high-CP treatments (Table 1). The CP:DOM ratio at 210 to 216 is related to the maximum feed intake (Reis et al., 2016). Although the results of Dong et al. (2017) and our results did not indicate changes in the energy intake between different CP:DOM ratios, an adequate protein:energy ratio should not be ignored because it may also affect nitrogen use (Reis et al., 2016).

The higher digestibilities of $\mathrm{CP}$ and NFC contributed significantly toincrease the digestibilities of DM, OM, and TDN since the aNDF digestibility was not modified. The maximum digestibility of $\mathrm{NDF}$ and $\mathrm{OM}$ is observed when a minimum of 7-8 \% CP is supplied (Lazzarini et al., 2009; Leng, 1990). However, the increase of CP level up to $13 \%$ may improve the rumen dynamics of NDF (Sampaio et al., 2009), which would be important in terms of intake limitation because of rumen fill. The lack of effect of CP level on aNDF digestibility and intake, as well as the high aNDF digestibility (approximately 70\%), indicate that rumen fill limitation was not the primary causal factor on DMI. Therefore, the metabolic constraints may have had a major effect on the regulation of feed intake. Thus, the voluntary intake was first limited by metabolic feedback regulations rather than by rumen fill (Illius \& Jessop, 1996). It can be confirmed by a similar TDN intake between treatments (Table 2).
The linear increase in apparent $\mathrm{N}$ digestibility with increasing CP levels is associated with a reduction in the proportion of metabolic fecal nitrogen in the total fecal $\mathrm{N}$ due to the increase in feed indigestible N. The linear increase in NFC digestibility may be the result of an increase in the amount of available $\mathrm{N}$ for rumen microorganisms. The high availability of N and NFC can stimulate microbial growth (Belanche et al., 2012).

Although high-concentrate diets were fed, the $\mathrm{pH}$ remained close to neutrality due to the effect of sodium carbonate and the large particle size of the hay. Serum urea nitrogen is highly correlated with $\mathrm{CP}$ intake and nitrogen excretion in the urine (Sampaio et al., 2010). The SUN is related to CP as well as to the amount of energy available in the rumen (Dong et al., 2017; Souza et al., 2010). The linear increase in SUN with increasing CP levels is due to the higher $\mathrm{CP}$ intake since the forage:concentrate ratio and energy intake were similar.

Low SUN is indicative of a lack of nitrogen in the rumen and may compromise microbial growth (Souza et al., 2010). On the other hand, high SUN is associated with decreased intake. Sampaio et al. (2010) reported that SUN levels above $20 \mathrm{mg} / \mathrm{dL}$ have a negative effect on DMI. None of the cows reached this upper limit for SUN, regardless of the CP level, and there was no change in the DMI. Particular attention should be paid to the SUN since it can be affected by both CP and energy. Souza et al. (2010) reported a decrease of 52\% in SUN when starch was added at the proportion of $20 \%$ of forage DM in a diet with $10 \% \mathrm{CP}$. The type of carbohydrate may determine the amount of ammonia in the rumen as well as the CP intake. Energy that is rapidly fermentable in the rumen would decrease ammonia production (Hristov et al., 2005). However, all cows were fed a similar type and amount of carbohydrate, and differences in SUN can be attributed to dietary CP levels.

Ammonia is the most important source of nitrogen for protein synthesis in the rumen (Dijkstra 
et al., 2013). The ammonia in the rumen originates from the degradation of the dietary true protein, from the non-protein nitrogen in the diet, the recycled urea- $\mathrm{N}$ in the rumen and the degradation of microbial cells in the rumen. Sampaio et al. (2010) reported that ruminal ammonia-nitrogen concentrations from 5 to $10 \mathrm{mg} / \mathrm{dL}$ are enough to supply the nitrogen substrates necessary to maintain the microbial activity in the rumen and to maximize voluntary feed intake. The dietary CP level of 9\% was enough to maintain the RAN concentration higher than $10 \mathrm{mg} / \mathrm{dL}$. The peak of RAN a few hours after feeding is the result of the high protein input and degradation by microorganisms in the rumen (Figure 1). The mean RAN is associated with the daily oscillation due to feeding. An increase in CP cannot ensure increased microbial activity. Koenig and Beauchemin (2013) observed that an increase in CP from 12 to $14 \%$ did not affect the DMI, the digestibilities of DM and NDF, or total ruminal VFA concentration. Although the $\mathrm{CP}$ levels increased the RAN concentration from 12 to $14-17 \mathrm{mg} / \mathrm{dL}$, the microbial protein synthesis and the efficiency of ruminal fermentation did not improve, indicating that the ruminal $\mathrm{NH}_{3}-\mathrm{N}$ was not limiting for ruminal microorganisms in heifers fed low CP diets.

Protein deposition increases linearly with increases in protein intake when protein supply is limiting, regardless of the energy level (Schroeder \& Titgemeyer, 2008). Nitrogen retention increases linearly with increases in protein intake until reaching the point where energy becomes most limiting. At that point, no further responses to protein intake are observed in many studies (Schroeder \& Titgemeyer, 2008). Although the CP level was not limiting for microbial activity, which can be demonstrated by the results of SUN and RAN, the increase in CP level was essential for the animal metabolism, which can be confirmed by the increase in nitrogen retained with the addition of $\mathrm{CP}$ in the diet (Table 5).

Nitrogen use efficiency in cattle is the proportion of feed $\mathrm{N}$ that is retained or captured in the body
(Dijkstra et al., 2013). Excess nitrogen in the form of either RDP or RUP is excreted in the urine mainly as urea nitrogen (Koenig \& Beauchemin, 2013). However, rumen metabolism has been identified as the most critical factor for the inefficiency of $\mathrm{N}$ use (Calsamiglia et al., 2010). High urinary urea nitrogen and urinary nitrogen levels indicate nitrogen waste. Besides economic losses, high $\mathrm{N}$ excretion is also related to energy losses. In terms of environmental pollution, urinary urea nitrogen has a greater impact on ammonia nitrogen emission and nitrogen loss from manure than fecal nitrogen (Koenig \& Beauchemin, 2013).

The use of $\mathrm{N}^{-\mathrm{NH}_{3}}$ as the only criterion for determining the minimum levels of nitrogen for optimal microbial growth should also be challenged (Calsamiglia et al., 2010). Besides the RAN concentration, the relationship between protein and energy may give valuable information about the efficiency of $\mathrm{N}$ use. In striving for the optimal supply of RDP and optimal efficiency of utilization of absorbed amino acids, the proper supply of energyyielding nutrients is crucial (Dijkstra et al., 2013). In attempts to improve NUE, changes in energy supply must be considered. For maximum NUE, the ratio between the crude protein to digestible organic matter content in the diet (CP:DOM) should be between 210 and $220 \mathrm{~g} \mathrm{CP} / \mathrm{kg}$ DOM (Detmann et al., 2014; Reis et al., 2016).

Strategies to reduce nitrogen losses should focus on an optimal supply of RDP and optimal efficiency of absorbed amino acid utilization for protein synthesis (Dijkstra et al., 2013). Higher nitrogen availability increases the proportion of total nitrogen that can be used for anabolic purposes and enhances the overall efficiency of the utilization of metabolizable protein. The hypothesis regarding the improvement of nitrogen status seems to be more plausible than the direct effect of an increased metabolizable protein supply since the increments in NUE were obtained with either protein or nonprotein nitrogen (Detmann et al., 2014). 
Urea synthesis requires ATP in the urea cycle (Nelson \& Cox, 2008). The relationship between $\mathrm{VO}_{2}$ and energy expenditure is due to the oxygen demand to produce ATP. Although the urea cycle is an energy-demanding process, the net cost of producing a molecule of urea is $1.5 \mathrm{ATP} / \mathrm{mole}$ (Nelson \& Cox, 2008). This energy cost represents a small fraction of the whole energy requirement for maintenance in ruminants.

In cows fed the $9 \% \mathrm{CP}$ treatment, the urea excretion was $1.04 \mathrm{~mole} / \mathrm{d}$, while it was $4.55 \mathrm{~mole} / \mathrm{d}$ in cows fed the $18 \% \mathrm{CP}$ diet. Since one mole of ATP is equivalent to $12 \mathrm{kcal}$ (Steinberg-Yfrach et al., 1998), the estimated energy costs for urea excretion were 12.5 and $54.6 \mathrm{kcal} / \mathrm{d}$ for cows fed diets with 9 and 18\% CP, respectively. The NRC (2001) states that the net energy requirement of a $300-\mathrm{kg}$ Holstein heifer is $6.01 \mathrm{Mcal} / \mathrm{d}$. Thus, given that $60 \%$ of urea can be recycled (Mutsvangwa et al., 2016), the estimated energy costs of urea excretion are 0.5 and $2.2 \%$ of the daily net energy requirement for maintenance in cows fed diets with 9 and $18 \% \mathrm{CP}$, respectively. Therefore, we estimated an increase of $0.7 \%$ in the daily net energy requirement for maintenance when dietary $\mathrm{CP}$ is increased from 9 to $18 \%$.

Although high dietary CP levels were not able to increase energy expenditure, the feed intake made a notorious contribution. The higher energy expenditure in the morning was the result of a high metabolic rate and activities associated with feeding since heifers had only a small space to walk. Eating and chewing require more than $10 \%$ of metabolizable energy (Susenbeth, Mayer, Koehler, \& Neumann,1998).

\section{Conclusion}

The increase of dietary CP levels from 9 to $18 \%$ does not improve the feed intake in heifers fed a high-concentrate diet. Moreover, the increase in $\mathrm{CP}$ levels improves the digestibility of $\mathrm{OM}$ and nitrogen retained. The energy expenditure is not changed with increasing $\mathrm{CP}$ levels. However, the energy expenditure increased during the daytime.

\section{Acknowledgements}

The authors wish to thank the Conselho Nacional de Pesquisa e Desenvolvimento Científico e Tecnológico (CNPQ) for Financial support.

\section{Disclosure statement}

There are no conflicts of interest with this research

\section{References}

Association of Official Analytical Chemists (1990). Official methods of analysis of AOAC International (15nd ed.). Washington, DC: AOAC.

Belanche, A., Doreau, M., Edwards, J. E., Moorb, J. M., Pinloche, E., \& Newbold, C. J. (2012). Shifts in the rumen microbiota due to the type of carbohydrate and level of protein ingested by dairy cattle are associated with changes in rumen fermentation. Journal of Nutrition, 142(9), 1684-1692. doi: $10.3945 /$ jn. 112.159574

Calsamiglia, S., Ferret, A., Reynolds, C. K., Kristensen, N. B., \& Van Vuuren, A. M. (2010). Strategies for optimizing nitrogen use by ruminants. Journal of Animal Bioscience, 4(7), 1184-1196. doi: 10.1017/ S1 751731110000911

Chaney, A. L., \& Marbach, E. P. (1962). Modified reagents for determination of urea and ammonia. Clinical Chemistry, 8(2), 130-132. Retrieved from http: webpages.icav.up.pt/ptdc/CVT/09848/2008/ Chaney,\% 20011962.pdf.

Detmann, E., Paulino, M. F., Valadares, S. C., F ${ }^{\circ}$, \& Lana, R. P. (2007). Fatores controladores de consumo em suplementos múltiplos fornecidos ad libitum para bovinos manejados a pasto. Cadernos Técnicos de Veterinária e Zootecnia, 55, 73-93

Detmann, E., Valente, É. E. L., Batista, E. D., \& Huhtanen, P. (2014). An evaluation of the performance and efficiency of nitrogen utilization in cattle fed tropical grass pastures with supplementation. Livestock Science, 162, 141-153. doi: 10.1016/j. livsci.2014.01.029 
Dijkstra, J., Reynolds, C. K., Kebreab, E., Bannink, A., Ellis, J. L., France, J., \& Van Vuuren, A. M. (2013). Challenges in ruminant nutrition: towards minimal nitrogen losses in cattle. In Energy and protein metabolism and nutrition in sustainable animal production (pp. 47-58). Wageningen Academic Publishers, Wageningen. Retrieved fromhttp://old.eaap.org/docs/members/9789086867 813EAAP134-e.pdf

Dong, L. F., Zhang, W. B., Zhang, N. F., Tu, Y., \& Diao, Q. Y. (2017). Feeding different dietary protein to energy ratios to Holstein heifers: effects on growth performance, blood metabolites and rumen fermentation parameters. Journal of Animal Physiology and Animal Nutrition, 101(1), 30-37. doi: 10. 1111/jpn.12493

Hristov, A. N., Ropp, J. K., Grandeen, K. L., Abedi, S., Etter, R. P., Melgar, A., \& Foley, A. K. (2005). Effect of carbohydrate source on ammonia utilization in lactating dairy cows. Journal of Animal Science, 83(2), 408-421. doi: 10.2527/2005.8324

Illius, A. W., \& Jessop, N. S. (1996). Metabolic constraints on voluntary intake in ruminants. Journal of Animal Science, 74(12), 3052-3062. doi: $10.2527 / 1996.74123052 x$

Koenig, K. M., \& Beauchemin, K. A. (2013). Nitrogen metabolism and route of excretion in beef feedlot cattle fed barley-based finishing diets varying in protein concentration and rumen degradability. Jornal of Animal Science, 91(5), 2310-2320. doi: $10.2527 /$ jas.2012-5653

Lazzarini, I., Detmann, E., Sampaio, C. B., Paulino, M. F., Valadares, S. C., $\boldsymbol{F}^{\boldsymbol{o}}$., Souza, M. A., \& Oliveira, F. B. (2009). Intake and digestibility in cattle fed low-quality tropical forage and supplemented with nitrogenous compounds. Revista Brasileira de Zootecnia, 38(10), 2021-2030. doi: 10.1590/S151635982009001000024

Leng, R. A. (1990). Factors affecting the utilization of "poor-quality" forages by ruminants particularly under tropical conditions. Nutrition Research Reviews, 3(1), 277-303. doi: 10.1079/NRR19900016

Licitra, G., Hernandez, T. M., \& Van Soest, P. J. (1996). Standardization of procedures for nitrogen fractionation of ruminant feeds. Animal Feed Science and Technology, 57(4), 347-358. doi: 10.1016/03 778401(95)00837-3

McLean, J. A. (1972). On the calculation of heat production from open-circuit calorimetric measurements. Bristish Journal of Nutrition, 27(3), 597-600. doi: 10.1079/BJN19720130
Mertens, D. R. (2002). Gravimetric determination of amylase-treated neutral detergent fiber in feeds with refluxing in beakers or crucibles: collaborative study. Journal of AOAC International, 85(6), 1217-1240.

Mutsvangwa, T., Davies, K. L., McKinnon, J. J., \& Christensen, D. A. (2016). Effects of dietary crude protein and rumen-degradable protein concentrations on urea recycling, nitrogen balance, omasal nutrient flow, and milk production in dairy cows. Journal of Dairy Science, 99(8), 6298-6310. doi: 10. 3168/ jds.2016-10917

Nelson, D. L., Lehninger, A. L., \& Cox, M. M. (2008). Lehninger principles of biochemistry. Macmillan.

National Research Council (2001). Requirements of dairy cattle (7nd ed.). Washington, D.C: Nutrient Requirements of Dairy Cattle. Natl. Acad. Press.

Reis, W. L. S., Detmann, E., Batista, E. D., Rufino, L. M. A., Gomes, D. I., Bento, C. B. P., \& Valadares, S. C., $\mathrm{F}^{\mathrm{o}}$. (2016). Effects of ruminal and post-ruminal protein supplementation in cattle fed tropical forages on insoluble fiber degradation, activity of fibrolytic enzymes, and the ruminal microbial community profile. Animal Feed Science and Technology, 218(23), 1-16. doi: 10.1016/j.anifeedsci.2016.05.001

Reynolds, C. K. (2006). Splanchnic metabolism of amino acids. In K. Sejrsen, T. Hvelplund, \& M. O. Nielsen (Eds.), Ruminant physiology. Digestion, metabolism and impact of nutrition on gene expression, immunology and stress. Wageningen Academic.

Reynolds, C. K., Crompton, L. A., \& Mills, J. A. N. (2011). Improving the efficiency of energy utilisation in cattle. Animal. Production Science, 51(1), 6-12. doi: 10.1071/AN10160

Richardson, D., Felgate, H., Watmough, N., Thomson, A., \& Baggs, E. (2009). Mitigating release of the potent greenhouse gas $\mathrm{N}_{2} \mathrm{O}$ from the nitrogen cycle - could enzymic regulation hold the key? Trends in Biotectechnology, 27(7), 388-397. doi: 10.1016/j. tibtech.2009.03.009

Sampaio, C. B., Detmann, E., Lazzarini, I., Souza, M. A., Paulino, M. F., \& Valadares, S. C., Fo . (2009). Rumen dynamics of neutral detergent fiber in cattle fed low-quality tropical forage and supplemented with nitrogenous compounds. Revista Brasileira de Zootecnia, 38(3), 560-569. doi: 10.1590/S1516-35 982009000300023

Sampaio, C. B., Detmann, E., Paulino, M. F., Valadares, S. C., Fo., Souza, M. A., Lazzarini, I., \& Queiroz, A. C. (2010). Intake and digestibility in cattle fed low-quality tropical forage and supplemented with 
nitrogenous compounds. Tropical Animal Health and Production, 42(10), 1471-1479. doi: 10.1007/ s11 250-010-9581-7

Schroeder, G. F., \& Titgemeyer, E. C. (2008). Interaction between protein and energy supply on protein utilization in growing cattle: a review. Livestock Science, 114(1), 1-10. doi: 10.1016/j.livsci.2007.12.0 08

Souza, M. A., Detmann, E., Paulino, M. F., Sampaio, C. B., Lazzarini, Í., \& Valadares, S. C., Fo . (2010). Intake, digestibility and rumen dynamics of neutral detergent fibre in cattle fed low-quality tropical forage and supplemented with nitrogen and/or starch. Tropical Animal Health and Production, 42(6), 1299-1310. doi: 10.1007/s11250-010-9566-6
SAS Institute Inc. (2017). Cary, NC; University Edition.

Steinberg-Yfrach, G., Rigaud, J. L., Durantini, E. N., Moore, A. L., Gust, D., \& Moore, T. A. (1998). Lightdriven production of ATP catalysed by F0F1-ATP synthase in an artificial photosynthetic membrane. Nature, 392 (6675,), 479-482. doi: 10.1038/33116

Susenbeth, A., Mayer, R., Koehler, B., \& Neumann, O. (1998). Energy requirement for eating in cattle. Journal Animal Science, 76(10), 2701-2705. doi: $10.2527 / 199876102701 x$ 
